\title{
Dowody, preferencje, rekomendacje. Manowce medycyny faktów - prezentacja przypadku chorego na raka gruczołowego płuca
}

\author{
Jolanta Winek ${ }^{1}$, Inga Barańska ${ }^{2}$, Zbigniew Jodkiewicz ${ }^{3}$, Renata Langfort ${ }^{4}$, \\ Tadeusz M. Orłowski ${ }^{5}$, Ewa Rogala ${ }^{1}$, Jerzy Usiekniewicz ${ }^{5}$, Kazimierz Roszkowski-Śliż ${ }^{1}$
}

Powszechna dostępność charakteryzujących się wysoką jakością badań wielorzędowych aparatów do tomografii komputerowej przyniosła znaczący wzrost wykrywania pojedynczych guzków płuca. Zważywszy na wysoką zapadalność na raka płuca i stale niezadowalające wyniki leczenia, możliwość wykrywania zmian mało zaawansowanych, poddających się doszczętnej resekcji, budziły duże nadzieje. Wykorzystywana w badaniach przesiewowych niskodawkowa tomografia komputerowa klatki piersiowej wskazuje na obecność pojedynczych guzków płuca nawet u 50\% palących papierosy osób powyżej 50 roku życia. Biorąc pod uwagę istotność problemu klinicznego, kluczowe jest ustalenie optymalnego sposobu diagnostyki pojedynczych guzków płuca. Pomocne w tym zakresie mogą być wytyczne American College of Chest Physcians. Wskazują one, iż w dokładnym oszacowaniu prawdopodobieństwa złośliwości zmiany należy oprzeć się na doświadczeniu klinicznym bądź też użyć jednego ze zweryfikowanych modeli typu Bayesian analysis. W poniższej pracy przedstawiamy przypadek chorego z pojedynczym guzkiem płuca, wskazując na rozbieżności decyzji diagnostycznych i terapeutycznych opartych na doświadczeniu diagnostów i klinicystów oraz wytycznych opartych na badaniach „kohortowych".

\section{Evidence-based medicine, a case report of adenocarcinoma of the lung}

Common access to high resolution computed tomography has increased the early detection of solitary lung nodules. The incidence of lung cancer is high with poor outcomes in the advanced stages of the disease. The best prognosis is achieved with complete surgical resection of a solitary small lung nodule. Low-dose computed tomography used as the screening test reveals solitary nodule in up to $50 \%$ of cigarettes smokers above 50 years of age. The guidelines of American College of Chest Physicians can be a helpful method to assess the potential malignancy of a nodule. Clinical experience and Bayesian analysis should be considered in a case of a suspected lung nodule on CT scans.

We present the case of a patient with a solitary lung nodule, and emphasise discrepancies between diagnostic and clinical assessment based on the evidence-based medicine guidelines.

NOWOTWORY Journal of Oncology 2015; 65, 5: 428-434

Słowa kluczowe: pojedynczy guzek płuca, gruczolakorak, PET-CT, Bayesian analysis, radioterapia adiuwantowa Key words: solitary pulmonary nodule, adenocarcinoma, PET-CT, Bayesian analysis, adjuvant radiotherapy

\author{
${ }^{1}$ III Klinika Chorób Płuc \\ Instytut Gruźlicy i Chorób Płuc w Warszawie \\ 2Zakład Radiologii \\ Instytut Gruźlicy i Chorób Płuc w Warszawie \\ ${ }^{3}$ Zakład Teleradioterapii \\ Centrum Onkologii — Instytut im. Marii Skłodowskiej-Curie w Warszawie \\ ${ }^{4}$ Zakład Patomorfologii \\ Instytut Gruźlicy i Chorób Płuc w Warszawie \\ ${ }^{5}$ Klinika Chirurgii Klatki Piersiowej \\ Instytut Gruźlicy i Chorób Płuc w Warszawie
}




\section{Wstęp}

Nowoczesne techniki obrazowania miąższu płuca, ich wysoka czułość przy powszechnej dostępności sprawiły, że pojedyncze guzki płuca stały się istotnym problemem klinicznym. Szacuje się, iż są one wykrywane w około 0,2\% do $7 \%$ radiogramów klatki piersiowej i około $25 \%$ tomografii klatki piersiowej (TK klp) [1]. The American College of Chest Physicians zaleca w procesie obserwacji pojedynczych guzków płucnych bardzo dokładne oszacowanie prawdopodobieństwa złośliwości zmiany. Wskazuje, iż należy oprzeć się na doświadczeniu klinicznym lub też użyć zweryfikowanych modeli takich jak Bayesian analysis [2]. Model Bayesian analysis opiera się na ocenie prawdopodobieństwa złośliwości zmiany uwzględniającej czynniki kliniczne i wynikające z badań wizualizacyjnych. Czynniki te to: wiek, historia palenia (paczkolata), krwioplucie, nowotwór złośliwy w przeszłości, wymiar (cm), lokalizacja, zarys, szybkość wzrostu, grubość ściany jamy, zwapnienie, wzmocnienie kontrastowe w TK klp wyrażone w jednostkach Hounsfielda (HU) oraz PET-CT, z których każdy posiada zróżnicowaną wagę oddziaływania na określenie prawdopodobieństwa złośliwości zmiany.

W poniższej pracy opisujemy przypadek chorego z przypadkowo wykrytym pojedynczym guzkiem płuca. Kluczowe dla pacjenta decyzje diagnostyczne i terapeutyczne oparto przede wszystkim na bogatym doświadczeniu lekarskim: onkologa, torakochirurga i radiologa. Istotnie odmienny przebieg niosłoby wykorzystanie modelu typu Bayesian analysis, którego jedną z wad wydaje się siła oddziaływania na ostateczny wynik badanie PET-CT. Rozbieżności decyzji opartych na doświadczeniu klinicznych oraz pozbawionym refleksji wykorzystaniu Bayesian analysis bądź PET-CT prezentujemy poniżej.

\section{Opis przypadku}

57-letni chory, wieloletni palacz papierosów (30 paczkolat) skierowany do Instytutu Gruźlicy i Chorób Płuc w celu diagnostyki przypadkowo wykrytego guzka płuca prawego. Wywiad chorobowy - obciążony nadciśnieniem tętniczym, chorobą niedokrwienną serca oraz hiperlipidemią. Zmianę w płucu prawym uwidoczniono w lipcu 2008 r. w radiogramie klp, wykonanym w trakcie hospitalizacji z przyczyn kardiologicznych. W TK klp opisano w segmencie tylnym płata górnego płuca lewego guzek lity $16 \mathrm{~mm} \times 17 \mathrm{~mm}$, ulegający silnemu wzmocnieniu kontrastowemu. W różnicowaniu brano przede wszystkim pod uwagę niedodmę okrągłą (niedodma płuca przybierająca kształt okrągły wywołana przewlekłym procesem chorobowym opłucnej) i guz płuca. Węzły chłonne wnęk i śródpiersia oceniono jako niepowiększone (ryc. 1). Wykonano również TK jamy brzusznej, stwierdzając w obrębie lewego nadnercza zmianę o charakterze gruczolaka. W celu dalszej diagnostyki guzka płuca pacjenta skierowano do oddziału chorób płuc, gdzie zdecydowano o wykonaniu PET-CT. Opisany guzek nie wykazywał wzmożonego metabolizmu 18-fluorodeoksyglukozy (18FDG), co sugerowało łagodny charakter zmiany i wiązało się z zaleceniem dalszej obserwacji.

W lutym 2009 r. w celu dalszej diagnostyki guzka chory zgłosił się do Instytutu Gruźlicy. Negował kaszel, duszność wysiłkową, chudnięcie oraz gorączkę. W kontrolnej TK klp opisano w segmencie 2 płuca prawego guzek o wymiarach około $19 \mathrm{~mm} \times 21 \mathrm{~mm}$. Zmiana przylegała do szczeliny międzypłatowej poziomej, odcinkowo pogrubiając ją. Przy szczelinie międzypłatowej skośnej prawej widoczny był drobny niespecyficzny guzek, ok. $4 \mathrm{~mm}$. Węzły chłonne wnęk niepowiększone, w śródpiersiu widoczne niepowiększone

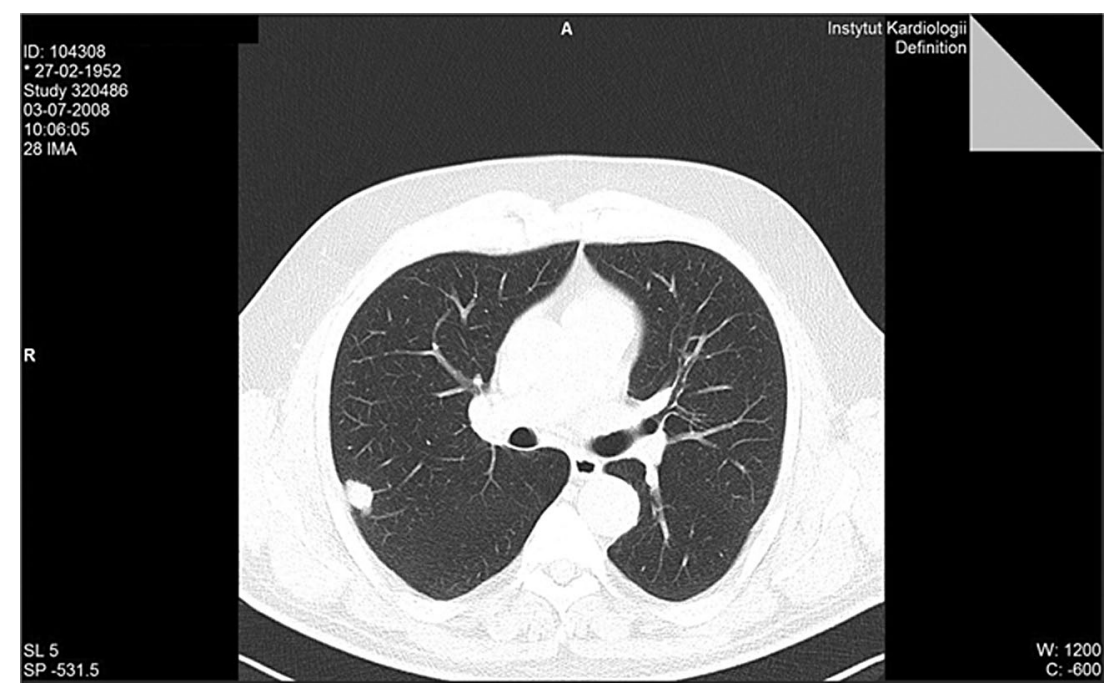

Rycina 1.W płacie górnym prawym, segment 2 guzek o wymiarach $14 \mathrm{~mm} \times 20 \mathrm{~mm}$. Zmiana przylegająca do szczeliny międzypłatowej poziomej ulega silnemu wzmocnieniu kontrastowemu i może odpowiadać niedodmie okrągłej lub guzowi (3.07.2008 r.) 
węzły chłonne przytchawicze dolne prawe ok. $7 \mathrm{~mm} \times 9 \mathrm{~mm}$, przytchawicze dolne lewe $7 \mathrm{~mm} \times 11 \mathrm{~mm}$ oraz okna aortalno-płucnego $10 \mathrm{~mm} \times 11 \mathrm{~mm}$. W porównaniu z badaniem TK klp z dnia 3 lipca 2008 r. (6-miesięczna obserwacja) zmiana ogniskowa w segmencie 2 płuca prawego była nieco większa, co budziło podejrzenie obwodowego guza płuca. Bronchoskopowo uwidoczniono prawidłowe drzewo oskrzelowe. Wykonano transtorakalną biopsję guzka, której wynik badania cytologicznego był niekonkluzywny. Zważywszy na policykliczny charakter zmiany, duże wzmocnienie kontrastowe, a zarazem powolny wzrost guzka u chorego z wysokim ryzykiem zachorowania na raka płuca zdecydowano o wykonaniu torakotomii z badaniem śródoperacyjnym. W marcu 2009 r. w trakcie przednio-bocznej torakotomii prawej resekowano klinowo wciągający ogniskowo opłucną płucną 2-centymetrowy guzek. W śródoperacyjnym badaniu mikroskopowym stwierdzono komórki raka niedrobnokomórkowego, prawdopodobnie gruczolakoraka. Wykonano lobektomię górną prawą z limfadenektomią śródpiersia. Przebieg pooperacyjny bez powikłań. Na podstawie badania mikroskopowego materiału pooperacyjnego rozpoznano ostatecznie raka gruczołowego, głównie o utkaniu zrazikowym, z komponentem brodawkowatym (pT2aNOROL1V1). W związku z ustalonym stopniem zaawansowania I B nie było wskazań do zastosowania leczenia uzupełniającego, i chory został poddany rutynowej kontroli przeprowadzanej w odstępach sześciomiesięcznych.

W listopadzie 2012 r. w kontrolnym badaniu TK klp uwidoczniono granicznej wielkości, choć większe niż poprzednio: węzeł chłonny przytchawiczy dolny prawy $17 \mathrm{~mm} \times 16 \mathrm{~mm}$ oraz węzeł podostrogowy $17 \mathrm{~mm} \times 13 \mathrm{~mm}$. Pozostałe węzły chłonne śródpiersia oraz wnęk były niepowiększone, okolica kikuta operowanego oskrzela bez cech wznowy miejscowej. Wykonano bronchofiberosonografię z przezoskrzelową biopsją węzłów grup 4R i 7. W badaniu cytologicznym materiału z obu grup węzłowych stwierdzono komórki raka niedrobnokomórkowego, prawdopodobnie gruczołowego. W związku z mikroskopowym potwierdzeniem wznowy regionalnej w okresie od 19 grudnia 2012 r. do 31 stycznia 2013 r. zastosowano u chorego napromienianie radykalne 3D z CBCT Fot.X $6 \mathrm{MeV}$ z 5 pól z zastosowaniem MLC w dawce dziennej 200 cGy/t do 6000 cGy/t w 30 frakcjach.

W kolejnej kontrolnej TK klp w kwietniu 2013 r., stwierdzono w segmencie 10 lewym, przy oskrzelu, ok. 7-milimetrowy guzek, niewidoczny w badaniu TK klp sprzed radioterapii, wykonanym w listopadzie 2012 r. Zdecydowano o ponownym wykonaniu PET-CT. Wynik badania wskazywał na aktywność metaboliczną: węzła chłonnego szyjnego dolnego prawego, guzka w płucu prawym oraz zmiany w trzonie lewej kości biodrowej z jednoznacznym wnioskiem: wznowa raka płuca.

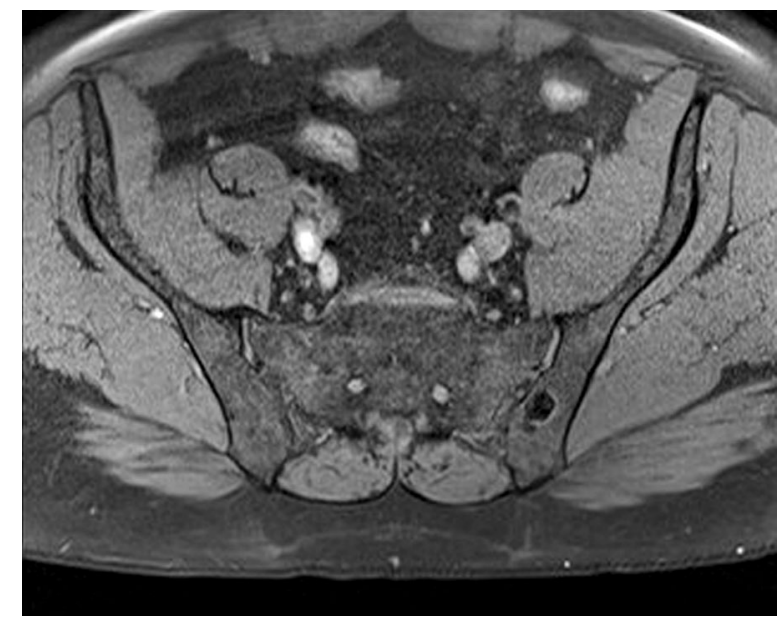

Rycina 2. Badanie MR kości biodrowych z kontrastem. W lewej kości biodrowej, przy stawie krzyżowo-biodrowym, uwidoczniono dobrze odgraniczoną zmianę bezsygnałową w T1, T2 i PD fat saturation, co wskazuje na jej osteosklerotyczny charakter, z rąbkiem podwyższonego sygnału w PD i T1 zal fat sat. Nie wykazano wzmocnienia kontrastowego ani ograniczenia dyfuzji w zmianie - obraz sugeruje wyspę kostną, która może wykazywać podwyższenie SUV w badaniu PET CT (18.06.2013 r.)

W celu weryfikacji charakteru zmiany w kości biodrowej wykonano rezonans magnetyczny (MRI) z kontrastem, który uwidocznił dobrze odgraniczoną zmianę o charakterze sugerującym wyspę kostną. Tego typu zmiana może wykazywać podwyższenie SUV w badaniu PET-CT (ryc. 2). Aktywne metabolicznie węzły szyjne oceniono w badaniu ultrasonograficznym. Uwidoczniono po stronie prawej pojedyncze, płaskie i wrzecionowate węzły chłonne szyjne z zaznaczonymi wnękami o zachowanej echostrukturze, które nie budziły niepokoju onkologicznego.

Niejasnym pozostawał charakter guzka w płacie środkowym. Biorąc pod uwagę wysokie ryzyko śród-i pooperacyjne, w czerwcu 2013 r. wykonano ponowną torakotomię. Po otwarciu całkowicie zarośniętej prawej jamy opłucnowej i wypreparowaniu prawego płuca stwierdzono w szczycie płata środkowego obecność około 11-milimetrowej zmiany guzkowej, którą wycięto z marginesem tkanek zdrowych. W śródoperacyjnym badaniu mikroskopowym stwierdzono ognisko tworzącego się zapalenia z obecnością pobudzonych, atypowych pneumocytów.W przebadanym materiale nie stwierdzono nacieku nowotworowego i w związku z tym nie poszerzono zakresu operacji. W przebiegu pooperacyjnym chory wymagał bronchofiberoaspiracji, antybiotykoterapii oraz intensywnej rehabilitacji oddechowej, co pozwoliło na stabilizację stanu klinicznego i rozprężenie się prawego płuca.

W ostatecznym badaniu mikroskopowym materiału pooperacyjnego stwierdzono zlewające się obszary śródmiąższowych zmian zapalnych z włóknieniem i organizującym się 


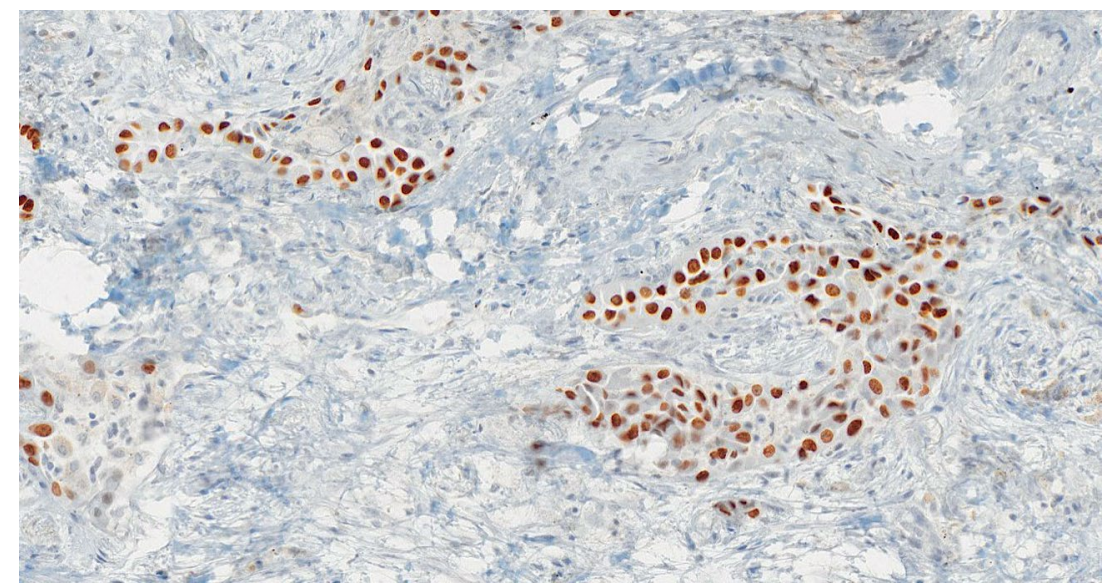

Rycina 3. Badanie immunohistochemiczne: TTF-1. Rozproszone ogniska nacieku raka gruczołowego wymieszane z tworzącym się zapaleniem płuca

zapaleniem, a wśród nich rozproszone i skupione w małych grupach komórki o cechach nasilonej atypii, podobne do stwierdzanych w materiale z biopsji igłowej węzłów śródpiersia. Całość obrazu, wyniki barwień oraz reakcji immunohistochemicznych (mucykarmin, TTF-1, Ki-67) odpowiadały rozproszonym komórkom raka gruczołowego ze zmianami w miąższu płuca, najprawdopodobniej o charakterze popromiennym (ryc. 3).

Chory pozostaje pod dalszą okresową kontrolą onkologiczną. W TK klp w lipcu 2014 nie stwierdzono nowych zmian. Utrzymują się powiększone jak poprzednio węzły chłonne przytchawicze dolne prawe $-11 \mathrm{~mm} \times 17 \mathrm{~mm}$.

\section{Omówienie}

Opis choroby prezentowanego pacjenta ukazuje trudności i pułapki w procesie diagnostyki i leczenia chorych z pojedynczym guzkiem płuca. Kluczowe na wstępie jest dokładne oszacowanie prawdopodobieństwa złośliwości zmiany. Zastosowanie na wstępnym etapie diagnostyki w lipcu 2008 r. zweryfikowanego modelu Bayesian analysis, uwzględniającego wiek chorego, historię palenia, wymiar, lokalizację i policykliczny zarys zmiany oraz wzmocnienie kontrastowe powyżej $15 \mathrm{HU}$, pozwoliło na ustalenie prawdopodobieństwa złośliwości guzka na poziomie 93\% (ryc. 4).

Kolejny etap diagnostyki guzka obejmował wykonanie badania PET-CT. Opisana zmiana nie wykazywała wzmożonego metabolizmu 18FDG, co mogło świadczyć o jej niezłośliwym charakterze i skutkowało zaleceniem dalszej obserwacji. Zastosowany na tym etapie model Bayesian analysis wskazywałby na prawdopodobieństwo złośliwości wynoszące 44\% (ryc. 5). Wynika to z bardzo dużej siły oddziaływania badania PET-CT ustalonej przez De-

\begin{tabular}{|c|c|}
\hline \multicolumn{2}{|c|}{ Analiza Bayesowska } \\
\hline Wstępny poziom prawdopodobieństwa złośliwości & Wprowadź liczbę od 1\% do $100 \%$ \\
\hline \multicolumn{2}{|l|}{ Charakterystyka kliniczna } \\
\hline Wiek & \begin{tabular}{|l|l|}
$50-59$ & v \\
\end{tabular} \\
\hline Historia palenia (paczkolata) & $30-39$ V \\
\hline Krwioplucie & Nieobecne $\boldsymbol{\nabla}$ \\
\hline Nowotwór złośliwy w przeszłości & Nie $\mathbf{~}$ \\
\hline \multicolumn{2}{|l|}{ Charakterystyka radiologiczna } \\
\hline Wymiar $(\mathrm{cm})$ & \begin{tabular}{|l|l|}
$1,1-2,0 \quad$ V \\
\end{tabular} \\
\hline Lokalizacja & \begin{tabular}{|l|l|} 
Górny/środkowy płat $\quad \nabla$ \\
\end{tabular} \\
\hline Zarys & \begin{tabular}{|l|l|} 
Policykliczny $\quad \boldsymbol{V}$ \\
\end{tabular} \\
\hline Szybkość wzrostu & \begin{tabular}{|l|l|} 
Nieznana $\quad \checkmark$ \\
\end{tabular} \\
\hline Grubość ściany: jamy & Bez jamy $\quad \checkmark$ \\
\hline Zwapnienie & Bez $\vee$ \\
\hline \multicolumn{2}{|l|}{ Informacje dodatkowe } \\
\hline Wzmocnienie kontrastowe & $>15 \mathrm{HU} \quad \nabla$ \\
\hline PET & $\begin{array}{|ll|}\text { Nie badano } \quad \mathbf{v} \\
\end{array}$ \\
\hline \multicolumn{2}{|c|}{ Wylicz prawdopodobieństwo } \\
\hline \multirow[t]{2}{*}{ Prawdopodobieństwo złośliwości zmiany } & 93 \\
\hline & Powrót \\
\hline
\end{tabular}

Rycina 4. Bayesian analysis; prawdopodobieństwo złośliwości zmiany wynosi 93\% 


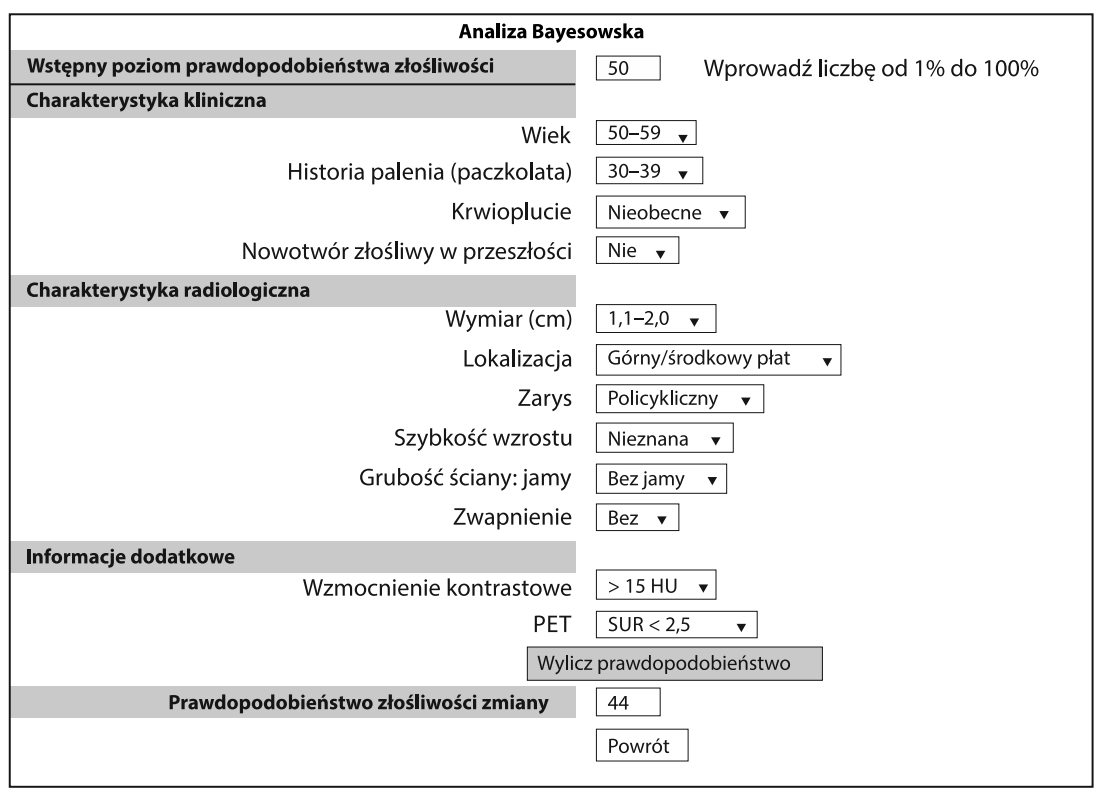

Rycina 5. Bayesian analysis; prawdopodobieństwo złośliwości zmiany wynosi $44 \%$

\begin{tabular}{|c|c|}
\hline \multicolumn{2}{|c|}{ Analiza Bayesowska } \\
\hline Wstępny poziom prawdopodobieństwa złośliwości & Wprowadź liczbę od 1\% do $100 \%$ \\
\hline \multicolumn{2}{|l|}{ Charakterystyka kliniczna } \\
\hline Wiek & $\begin{array}{|ll|}50-59 & \text { v } \\
\end{array}$ \\
\hline Historia palenia (paczkolata) & $30-39$ V \\
\hline Krwioplucie & Nieobecne $\mathbf{v}$ \\
\hline Nowotwór złośliwy w przeszłości & Nie $\checkmark$ \\
\hline \multicolumn{2}{|l|}{ Charakterystyka radiologiczna } \\
\hline Wymiar $(\mathrm{cm})$ & $1,1-2,0 \quad \vee$ \\
\hline Lokalizacja & Górny/środkowy płat $\quad \nabla$ \\
\hline Zarys & \begin{tabular}{|ll} 
Policykliczny $\quad \boldsymbol{}$ \\
\end{tabular} \\
\hline Szybkość wzrostu & Powolna $\checkmark$ \\
\hline Grubość ściany: jamy & Bez jamy $\quad \nabla$ \\
\hline Zwapnienie & Bez $\checkmark$ \\
\hline \multicolumn{2}{|l|}{ Informacje dodatkowe } \\
\hline Wzmocnienie kontrastowe & $>15 \mathrm{HU} \quad \nabla$ \\
\hline PET & SUR $<2,5$ \\
\hline \multicolumn{2}{|c|}{ Wylicz prawdopodobieństwo } \\
\hline \multirow[t]{2}{*}{ Prawdopodobieństwo złośliwości zmiany } & 1 \\
\hline & Powrót \\
\hline
\end{tabular}

Rycina 6. Bayesian analysis; prawdopodobieństwo złośliwości zmiany wynosi 1\%

wana i wsp., którzy we wnioskach ze swojego doniesienia wskazują, iż badanie PET-CT jest najlepszym czynnikiem predykcyjnym złośliwości pojedynczych guzków płucnych w porównaniu ze standardowymi kryteriami stosowanymi w Bayesian analysis [3].

Późniejsze badania nie potwierdziły słuszności tego twierdzenia w stosunku do raka gruczołowego, w którym to typie histologicznym badanie PET-CT posiada największy odsetek wyników fałszywie ujemnych [4,5].

W kolejnym badaniu TK klp, wykonanym w lutym 2009 r., czyli po 6 miesiącach obserwacji, wielkość guzka wynosiła około $19 \mathrm{~mm} \times 21 \mathrm{~mm}$. Uwzględnienie powolnego tempa wzrostu w ponownej analizie Bayesian skutkowałoby oszacowaniem prawdopodobieństwa złośliwości na 1\% (ryc. 6).

Jednakże bardzo sugestywne cechy radiologiczne w postaci policyklicznego zarysu zmiany i dużego wzmocniania kontrastowego u chorego z wysokim ryzykiem zachorowania na raka płuca, pomimo niskiej aktywności metabolicznej 18FDG w badaniu PET-CT, skłoniły do decyzji o leczeniu operacyjnym. Jej słuszność potwierdziło badanie mikroskopowe materiału pooperacyjnego, w którym stwierdzono utkanie raka gruczołowego w stopniu zaawansowania pT2aNOROL1V1. Ustalenie stopnia zaawansowania procesu jako IB zdecydowało o wyłącznie dalszej okresowej kontroli. 
W listopadzie 2012 r. w kontrolonym badaniu TK klp stwierdzono powiększenie uwidocznionych już w lutym 2009 r. węzłów chłonnych przytchawiczych dolnych prawych i podostrogowych. Badanie cytologiczne materiału z biopsji przezoskrzelowej potwierdziło podejrzenie wznowy regionalnej. Zdecydowano o radioterapii na okolicę wznowy.

Powstaje w tym miejscu pytanie: czy wobec wznowy regionalnej u chorego po radykalnej resekcji raka płuca nie powinno się zastosować radioterapii elektywnej?

Metaanaliza badań nad rolą pooperacyjnej radioterapii w NDRP dokonana przez PORT Meta-analysis Trialists Group [6] oparta była na danych pochodzących z siedmiu publikowanych badań randomizowanych [7-13] oraz dwóch badań niepublikowanych: European Organisation for Research and Treatment of Cancer 08861 i Lung Cancer Study Group (LCSG) 841.

Łącznie dokonano analizy 2128 przypadków po doszczętnych zabiegach resekcyjnych, poddanych randomizacji do grupy napromienianych pooperacyjnie i grupy bez leczenia uzupełniającego. Metaanaliza ta wykazała pogorszenie o 7\% dwuletniego przeżycia w grupie chorych poddanych pooperacyjnej radioterapii (48\%) w porównaniu z grupą bez interwencji (55\%).

Wykazano 21-procentowy wzrost względnego ryzyka zgonu, który związany był prawie całkowicie z pogorszeniem przeżycia napromienianych chorych w I ill stopniu zaawansowania i wiązany był z toksycznością radioterapii. U chorych z cechą N2 napromienianie nie miało ani pozytywnego, ani negatywnego wpływu na rokowanie.

Wyniki przedstawionego badania spotkały się z dużą dozą krytyki zarówno z powodu różnorodności w zakresie metod oceny stopnia zaawansowania choroby, szczególnie cechy $\mathrm{N}$, jak również, a może przede wszystkim, w związku z dominującym wpływem wyników jednego badania, w którym obserwowano szczególnie dużą częstość zgonów toksycznych [8]. W badaniu tym zastosowano dawkę radioterapii uzupełniającej doszczętne leczenie chirurgiczne w wysokości $60 \mathrm{~Gy}$. Co więcej, badanie to było dominujące pod względem liczebności w stosunku do wszystkich pozostałych badań objętych metaanalizą - dotyczyło 728 chorych, spośród których u 221 stwierdzono I stopień zaawansowania, u 180 - II, u 327 - III.

Oryginalnymi, ale niepotwierdzonymi w innych doniesieniach są wyniki świadczące o tym, że radioterapia pooperacyjna nie ma istotnego wpływu na częstość wznów miejscowych oraz że częstość zgonów niezwiązanych z chorobą nowotworową wzrasta wraz z dawką frakcyjną zastosowanego napromieniania. W tym miejscu wypada powołać się na bardzo przekonujące doniesienie Mitchella Machtaya i wsp., którzy porównali częstość zgonów u chorych poddanych pooperacyjnej radioterapii zzastosowaniem nowoczesnych technik planowania leczenia z częstością zgonów z powodu chorób współistniejących u dopasowanych pod względem płci i wieku chorych nieotrzymujących pooperacyjnej radioterapii i nie wykazali znamiennej statystycznie różnicy [14].

W 2002 roku Trodella i wsp. opublikowali wyniki randomizowanego badania III fazy, w którym oceniano efektywność adiuwantowej radioterapii u chorych na NDRP jedynie w pierwszym stopniu zaawansowania (T1N0, T2N0). Wyniki tego badania pozostają w skrajnej sprzeczności z wynikami omawianej wcześniej metaanalizy. Spośród 51 chorych operowanych i następnie napromienianych dawką 50,4 Gy z frakcjonowaniem 1,8 Gy dziennie przez 5 tygodni i 3 dni wznowę miejscową zanotowano jedynie w jednym przypadku (2,2\%). Natomiast w grupie kontrolnej 53 chorych leczonych jedynie operacyjnie wznowa regionalna wystąpiła u 12 chorych (23\%). Obserwowano również korzystny trend w pięcioletnim przeżyciu wolnym od choroby u chorych napromienianych pooperacyjnie (67\% vs 58\%; $p=0,048)$ [15].

Badanie to nie dowodzi w sposób oczywisty skuteczności pooperacyjnej radioterapii w kontekście wpływu na wydłużenie przeżycia chorych, natomiast potwierdza hipotezę, że racjonalnie stosowana nowoczesna radioterapia nie wiąże się z nieakceptowalną toksycznością u chorych operowanych z powodu NDRP. Istotną wartością wynikającą z tego badania jest również to, że wobec obecnie obowiązujących kryteriów oceny stopnia zaawansowania cechy $\mathrm{N}$ i technik leczenia chirurgicznego tak wysoki odsetek wznów regionalnych (23\%) może jednak stanowić przesłankę do zastosowania pooperacyjnej radioterapii w ramach rutynowej praktyki klinicznej, szczególnie w ośrodkach posiadających gorsze wyniki leczenia chirurgicznego [16].

W wykonanej niespełna 3 miesiące od zakończenia radioterapii TK klp w kwietniu 2013 r. stwierdzono obecność w segmencie 10 lewym 7-milimetrowego guzka. Zdecydowano o ponownym wykonaniu PET-CT, które wykazało obecność aktywnych metabolicznie ognisk w węzłach chłonnych szyjnych prawych, w szczycie prawego płuca i lewej kości biodrowej, a wniosek końcowy brzmiał: wznowa raka płuca.

Dalsza diagnostyka różnicowa wykluczyła nowotworowy charakter zmian w węzłach i kości biodrowej, przy niejednoznacznym, a głównie jednak zapalnym charakterze zmiany w płucu. Na uwagę zasługuje fakt, że u tego samego chorego doszło dwukrotnie do niespecyficznego wyniku badania PET, w diagnostyce wstępnej fałszywie ujemnego, zaś w monitorowaniu przebiegu pooperacyjnego fałszywie dodatniego. Ograniczenia wynikające ze swoistości tego badania w diagnostyce nawrotu po leczeniu operacyjnym były również przedmiotem publikacji [17].

Zwiększony metabolizm FDG w szczycie prawego płuca związany był z dominującymi w obrazie histologicznym obszarami zlewającego się, tworzącego się zapalenia. Jeżeli przyjąć za pewną obecność rozproszonych komórek raka gruczołowego, to trudno sobie wyobrazić, aby niewielka 
liczba komórek nowotworowych mogła być odpowiedzialna za zwiększenie metabolizmu w 7-milimetrowym ognisku zapalnym.

Jednakże w tym miejscu powstaje kolejne pytanie: czy w przypadku usuniętego chirurgicznie mikroprzerzutu należało u chorego zastosować chemioterapię? Na pytanie to nie można odpowiedzieć bez rozważenia mechanizmu, w jakim doszło do powstania ogniska zapalnego z rozproszonymi komórkami raka. Najbardziej racjonalnym wytłumaczeniem takiego stanu rzeczy jest odczynowa reakcja zapalna na obecność komórek nowotworowych w miąższu płucnym. W przypadku nowotworu o niskiej chemiowrażliwości i dużej reaktywności gospodarza można sobie wyobrazić, że leczenie immunosupresyjne mogłoby wyzwolić zjawisko wzmocnienia wzrostu guza. Zjawisko wzmocnienia wzrostu guza (The Tumor Enhancement Phenomenon), opisane po raz pierwszy ponad wiek temu, znane jest z licznych doniesień eksperymentalnych i nierzadko obserwowane w praktyce klinicznej w przypadku chorych z nowotworami w stanie immunosupresji oraz w przebiegu paradoksalnych odpowiedzi na chemioterapię $[18,19]$.

Reasumując, przedstawiony przypadek długoletniego przeżycia chorego na raka gruczołowego ze wznową regionalną i prawdopodobnym ogniskiem mikroprzerzutowym w tym samym płucu aktualnie bez objawów aktywnego procesu nowotworowego skłania do refleksji nad celowością indywidualizacji postępowania, a nie myśleniem „kohortowym".

Wydaje się, iż pomimo tego, że współczesna medycyna oparta jest na faktach, to jednak nadal pozostaje sztuką.

\section{Konflikt interesów: nie zgłoszono}

\section{Dr n. med. Jolanta Winek}

\section{OddziałX}

Instytut Gruźlicy i Chorób Płuc

ul. Płocka 26, 01-138 Warszawa

e-mail:j.winek@igichp.edu.pl

Otrzymano: 19 maja 2015 r.

Przyjęto do druku: 4 sierpnia 2015 r.

\section{Piśmiennictwo}

1. Aberle D, DeMello S, Berg CD i wsp. Results of the two incidence screenings in the National Lung Screening Trial. NEJM 2013; 369; 920-931.
2. Gould MK, Fletcher J, lannettoni MD i wsp. Evaluation of patients with pulmonary nodules: when is it lung cancer?: ACCP evidence-based clinical practice guidelines (2nd edition). Chest 2007; 132 (3 Suppl): 108S-130S.

3. Dewan NA, Shehan CJ, Reeb SD i wsp. Likelihood of malignancy in a solitary pulmonary nodule: comparison of Bayesian analysis and results of FDG-PET scan. Chest 1997; 112: 416-422.

4. Nomori H, Kosaka N, Watanabe K i wsp. 11C-acetate positron emission tomography imaging for lung adenocarcinoma 1 to $3 \mathrm{~cm}$ in size with ground-glass opacity images on computed tomography. Ann Thorac Surg 2005; 80: 2020-2025.

5. Opoka L, Kunikowska J, Podgajny Z i wsp. Accuracy of FDG PET/CT in the evaluation of solitary pulmonary lesions - own experience. Pneumonol Alergol Pol 2014; 82: 198-205.

6. Postoperative radiotherapy in non-small-cell lung cancer: systematic review and metaᄀanalysis of individual patient data from nine randomised controlled trials. PORT Meta-analysis Trialists Group. Lancet 1998; 352: 257-263.

7. Effects of postoperative mediastinal radiation on completely resected stage II and stage III epidermoid cancer of the lung. The Lung Cancer Study Group. NEJM 1986; 315: 1377-1381.

8. Dautzenberg B, Arriagada R, Chammard AB i wsp. A controlled study of postoperative radiotherapy for patients with completely resected non-small-cell lung carcinoma. Groupe d'Etude et de Traitement des Cancers Bronchiques. Cancer 1999; 86: 265-273.

9. Debevec M, Bitenc M, Vidmar S i wsp. Postoperative radiotherapy for radically resected $\mathrm{N} 2$ non-small-cell lung cancer (NSCLC): randomised clinical study 1988-1992. Lung Cancer 1996; 14: 99-107.

10. Lafitte JJ, Ribet ME, Prevost BM i wsp. Postresection irradiation for T2 NO MO non-small cell carcinoma: a prospective, randomized study. Ann Thorac Surg 1996; 62: 830-834.

11. Stephens RJ, Girling DT, Bleehen NM i wsp. The role of post-operative radiotherapy in non-small-cell lung cancer: a multicentre randomised trial in patients with pathologically staged T1-2, N1-2, M0 disease. Medical Research Council Lung Cancer Working Party. Br J Cancer 1996; 74: 632-639.

12. Van Houtte P, Rocmans P, Smets P i wsp. Postoperative radiation therapy in lung cancer: a controlled trial after resection of curative design. Int $J$ Radiat Oncol Biol Phys 1980; 6: 983-986.

13. Yom SS, Liao Z, Liu HH i wsp. Initial evaluation of treatment-related pneumonitis in advanced-stage non-small-cell lung cancer patients treated with concurrent chemotherapy and intensity-modulated radiotherapy. Int J Radiat Oncol Biol Phys 2007; 68: 94-102.

14. Machtay M, Lee JH, Shrager JB i wsp. Risk of death from intercurrent disease is not excessively increased by modern postoperative radiotherapy for high-risk resected non-small-cell lung carcinoma. J Clin Oncol 2001; 19: 3912-3917.

15. Trodella L, Granone P, Valente S i wsp. Adjuvant radiotherapy in nonsmall cell lung cancer with pathological stage I: definitive results of a phase III randomized trial. Radiother Oncol 2002; 62: 11-19.

16. Rami-Porta R, Wittekind C, Goldstraw P. International Association for the Study of Lung Cancer (IASLC) Staging Committee. Complete resection in lung cancer surgery: proposed definition. Lung Cancer 2005; 49: 25-33.

17. Opoka L, Szołkowska M, Podgajny Z i wsp. Assessment of recurrence of non-small cell lung cancer after therapy using CT and Integrated PET/CT. Pneumonol Alergol Pol 2013; 81: 214-220.

18. Flexner $\mathrm{S}$, Jobling JW. On the promoting influence of heated tumor emulsions on tumor growth. Proc Soc Exp Biol Med 1907; 4: 156-169.

19. Bordin JO, Bardossy L, Blajchman MA. Growth enhancement of established tumors by allogeneic blood transfusion in experimental animals and its amelioration by leukodepletion: the importance of the timing of the leukodepletion. Blood 1994; 84: 344-348. 